\title{
Sócrates: viejas y nuevas interpretaciones
}

\author{
Francisco Rodríguez Adrados \\ ILC, CSIC \\ fradrados@gmail.com \\ Socrates: old and new interpretations
}

El autor, que comenzó a publicar sobre Sócrates hace ya muchos años, como discípulo de D. Antonio Tovar le dedica hoy este trabajo, reflexionando sobre lo mucho que desde entonces se ha escrito y pensado. Sócrates no tuvo una doctrina, sólo buscaba apoyo racional a la creencia tradicional en virtudes fijas. Pero intentaba crear a partir de aquí una nueva idea de la divinidad, que culminó en Platón. Y se apoyaba también en la antigua Literatura oral y sapiencial.

Palabras clave: El dios / los dioses; daimonion; política; valor; Platón; democracia; sofistas; religión tradicional.
A la memoria de D. Antonio Tovar, que me llevó a Sócrates hace ya muchos años many years ago, dedicates this paper to Prof. Antonio Tovar, of whom he was a disciple, and reflects on how much has been written and thought since then. Socrates did not have a doctrine, he only sought rational support for traditional beliefs in fixed virtues. Starting from this premise, he tried to create a new idea of divinity, which actually reached its peak with Plato. He also used age-old oral and sapiential literature as a source.

Key words: The god/the gods; daimonion; politics; value; Plato; democracy; Sophists; traditional religion.

\section{UN PRIMER PANORAMA}

Sócrates era, parece que al menos en esto todos estamos de acuerdo, una personalidad muy compleja, las mismas acusaciones que se le hicieron así lo hacen ver.

A saber: según la acusación, recogida tanto en la Apología de Platón como en la de Jenofonte, no creía en los dioses de la ciudad y corrompía a los jóvenes, lo cual parece que quiere decir lo mismo. Pero constantemente habla-

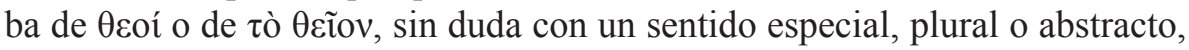




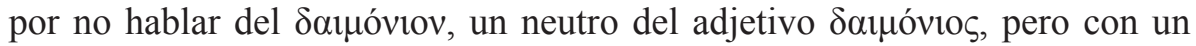
valor ya activo y personal o no, racional o irracional, según los distintos estudiosos ${ }^{1}$.

Prescindiendo ahora de viejas propuestas como la de que lo que se le atribuía era puro mito o de que los que le condenaron a muerte tenían razón ${ }^{3}$. El daimónion o ente divino que le aconsejaba o desaconsejaba sería un nuevo dios, que le ayudaba, a veces, a tomar sus decisiones. ¿Y pretendía Sócrates, como se dice, una innovación en el comportamiento humano, en la ética y la religión por ejemplo? Es seguro que sí, investigaba, así se dice sobre todo en los diálogos menores de Platón y en la Apología platónica.

Investigaba las distintas virtudes o comportamientos: qué son la piedad, el valor, etc., así como los diálogos menores de Platón (el Cármides, el Laques, el Lisis, el Eutifrón, el Eutidemo a más del Critón y la Apología). Intentaba que quedara claro qué comportamiento era el legítimo, el que él recomendaba. Distinguía entre tò $\alpha \gamma \alpha \theta$ óv, el bien, que era pura ventaja, y el que tenía un valor moral.

En suma, buscaba y buscaba: por tanto, no se le puede atribuir una doctrina absolutamente definida. Y su investigación se refería siempre al tema de la conducta humana, era algo semejante a lo que en el dominio de la meteorología, hablemos en términos griegos, hacían los sofistas en el mundo físico o natural que decimos ahora, como se quiera. Lo mismo hacía Sócrates, según Aristófanes en su comedia Las Nubes de 423 a. C.

Era Sócrates, por otro lado, un hombre raro. Era un hijo del pueblo, de un escultor, más bien artesano, que había servido como hoplita en el ejército ateniense en Amfípolis, en Potidea, en Delion. Resistía en las más difíciles circunstancias, paseaba descalzo sobre el hielo, era arrebatado por una especie de éxtasis. Era feo como un Sileno, pero bello por dentro. Atraía con un amor extraordinario, pero era ajeno al deseo. Todo lo resistía: tras un simposio con Alcibíades, a la noche, salía paseando impávido. Estaba casado con una mujer prototipo de la vulgaridad, Jantipa, mantenía la calma. Y tenía tres hijos. ¿De qué vivía? No sabemos. Unía una vida vulgar y lo extraordinario.

\footnotetext{
${ }^{1}$ Véase en Smith y Woodruff (eds.) 2000, pp. 176-204, el debate (en cartas) entre G. Vlastos y varios filólogos: Vlastos rechazaba todo compromiso frente al racionalismo de Sócrates, otros afirmaban que el daimónion era una fuente de saber irracional.

${ }^{2}$ Así Dupréel 1922, para quien sería una ficción literaria; Gigon 1947, para quien más que un maestro sería la imagen central de la poesía filosófica.

${ }^{3}$ Cf. Fréret 1738. Véase también Gómez Robledo 1966, p. 236.
} 
Según la interpretación de algunos, entre ellos sus jueces, Sócrates siguió haciendo «meteorología» hasta su muerte. Es decir, comportándose como un sofista, negando la parcela de poder de los dioses. Un error, protestaba él. Pero en todo caso ello le llevó a la muerte, al negar, aunque fuera sólo tácitamente, el papel de los dioses en el mundo sobrehumano: el de los cuerpos celestes y el de los fenómenos meteorológicos. Los griegos unían uno y otro sector en la palabra $\mu \varepsilon \tau \varepsilon \dot{\omega} \omega \rho \alpha$ «las cosas de lo alto».

Y todos le apreciaban, de los hombres del pueblo a los nobles, los clientes de las peluquerías, los efebos de las palestras, de todos era amigo. ¿De qué vivía este hombre? No sabemos.

En todo caso, igual que los sofistas, e independientemente de cuáles habían sido sus comienzos, no aceptaba la tradición, buscaba. Pero en el mundo moral, humano. Así nos es presentado en los escritos de Platón y Jenofonte relativos a sus últimos tiempos, antes de su muerte.

Y aquí viene el gran tema: ¿seguía o no Sócrates, el Sócrates que conocemos, la religión tradicional? Jenofonte se inclinaba al sí, varios autores modernos le siguen. Pero la cosa no es tan clara, su adhesión al culto de los dioses de Atenas podía ser ya un resto tradicional, ya una estrategia defensiva para evitarse riesgos. Porque algunos pensamos que en alguna medida sobrevivían en su ser más profundo huellas de esas antiguas creencias o vivencias. Y que ello ayuda a comprender que su sucesor fuera Platón, un hombre religioso pero con matices nuevos.

En todo caso, no hay duda de que Sócrates fue un inconformista que buscaba una Ciencia de tipo racionalista, no se contentaba con datos o creencias procedentes de la vieja tradición griega.

Voy a comentar ahora algunas publicaciones sobre Sócrates para ver en qué medida se ha avanzado o puede avanzarse en su conocimiento, más allá de la visión general que acabo de dar. Y voy a comenzar por la Vida de Sócrates de Antonio Tovar, de $1947^{4}$, cuyas pruebas corregí siendo todavía estudiante y que influyó evidentemente en un artículo mío de $1956^{5}$. Algunas cosas más publiqué más tarde. Y quiero contrastar esto con la nueva bibliografía.

Sócrates sigue tentándome, es un tema tan sugestivo como difícil. Es un hombre que, como se sabe, no escribió, lo conocemos sólo por referencias o relatos cuya crítica causa problemas.

${ }^{4}$ Tovar 1947, $2^{\text {a }}$ ed. 1954.

${ }_{5}$ Rodríguez Adrados 1956. 
Después comentaré aportaciones posteriores de varios autores a la cuestión socrática, tratando de poner de relieve lo que hemos aprendido sobre el tema de la nueva bibliografía. Y añadiré también un comentario sobre varias publicaciones de varios autores posteriores a estas. Pero sigo ahora con el libro de Tovar.

En España, por los años 40 del siglo XIX había surgido un nuevo ambiente favorable al estudio de los clásicos greco-latinos. La revista Emerita, fundada en 1933, fue un buen antecedente de ello. Había ahora bibliotecas y revistas y grupos de estudiosos. Antonio Tovar era quizá el primero de estos. Veía en Sócrates un intento de renovación del espíritu, de crear una sociedad estable y avanzada, en conexión sin duda con ciertas ensoñaciones de aquellos tiempos.

$\mathrm{Su}$ Vida de Sócrates fue seguramente su mejor libro. Aunque yo no dudaba de que era un ensayo sujeto, como todo, a revisión. En España causó impacto, fuera fue más bien ignorado, como tantas cosas que aquí publicábamos (y publicamos). Creo que el libro merece, al menos, ser recordado. Ya di la fecha de su publicación y de su segunda edición.

Para Tovar, Sócrates era el renovador (o aspirante a renovador) de Atenas y del mundo, y tras él llegó Platón, otro aspirante a la renovación del mundo. Aspiraba a que su generación trajera esta renovación, tras las desgracias de la guerra del Peloponeso. Intentaba sembrar una antigua sabiduría que, la verdad, es claro que fue rechazada en Atenas por los más, pero dejó huella profunda. Era Sócrates, en realidad, un predicador, anunciaba una buena nueva que Atenas necesitaba. Pero un predicador familiar, amigo, dialogante. Así veía a Sócrates Tovar, que miraba, en tanto, a España.

Tovar, en cierto modo, se asimilaba a sí mismo a Sócrates, cambiando Grecia por España, creía en el valor renovador de la antigua Sabiduría que él introducía en nuestro país.

Sócrates era, repetía y repetía en su libro, el cordón umbilical que unía o pretendía unir a la vieja Atenas con la nueva, nos la traía. Y nosotros, en aquel momento de España, la renovábamos, o eso creíamos, con la Ciencia griega de antaño. Sócrates amaba a Atenas, al Ilisos y otras aguas antiguas, impulsaba el nuevo saber que, descendiente del antiguo, iba a vivificar, con él, la vieja Atenas. Sócrates, pese a los intentos de Critón, no la abandonaría, no la traicionaría, viviría en ella aunque fuera en la cárcel, sería injusto abandonarla después que con sus leyes y su sabiduría le había criado, como dijo en ese diálogo, el Critón.

Sócrates, repito, debía gratitud a Atenas que le había criado, así se manifiesta en el Critón sobre todo. Había luchado por la ciudad en los campos de 
batalla, había participado en sus instituciones, tales la Asamblea y los tribunales, había, eso sí, usado la libertad de palabra que concedía la democracia para tratar de impedir un grave error como fue la condena a muerte de los generales vencedores en las Arginusas, en el 406, que no pudieron, por causa de la tempestad, recuperar los cadáveres de los atenienses muertos.

Una ola de irracionalidad invadía a Atenas. Pero Sócrates se negó también, con riesgo de su vida, a hacerse cómplice de los crímenes de los treinta tiranos, en el 403.

Y se defendió con valor en el juicio en el que se le acusó, en el 399, de no rendir culto a los dioses de los atenienses y corromper a los jóvenes. Ya se preveía el fatal resultado del juicio, Critón, su discípulo y amigo, le visitó luego en la cárcel y le propuso huir, ya lo dije, todo estaba preparado. Pero eso sería una traición a Atenas, respondió Sócrates, a la que todo se lo debía, y prefirió enfrentarse a la muerte. Una muerte aceptada voluntariamente, que fue lo más importante de su vida, lo que más hizo por su nombre.

Una decisión unívoca, aunque sobre su pensamiento podamos tener dudas, aunque no que las tuviera un hombre que buscaba simplemente la verdad dentro de una situación religiosa, intelectual, humana muy compleja. Pero no las tenía porque era Sócrates. Y pretendía que todos fueran así.

Prefería la cárcel y aun la muerte antes que rebelarse contra Atenas. Los valores de la ciudad estaban por delante de cualquier otro. Le acusaban de irreligión y de corromper a la juventud cuando él buscaba simplemente una nueva firmeza moral, unas decisiones fundadas en el lógos. Sus propuestas eran algo así como las de Isócrates en su Panegírico. Buscaba refundar la ciudad, dar a la vida y a las decisiones de los ciudadanos una base firme, inspirada en la de los antiguos atenienses, pero con un fundamento racional.

Pero, antes de seguir adelante, querría recordar esas antiguas propuestas de Antonio Tovar y una mía en relación con este tema.

Para Tovar lo que Sócrates pretendía era una renovación de la ciudad, sacándola de comportamientos vacilantes y débiles y creando una nueva virtud. Sócrates sería como un cordón umbilical que renovaba la Atenas de sus días con ayuda de su antiguo ser.

Sería una renovación apoyada en antiguos modelos. Algo así como cuando Isócrates ofrecía, en sus discursos, ya lo dije, con sus debates o prédicas, una renovación de los valores de sus días, con ayuda de los de los viejos atenienses, los que derrotaron a los invasores asiáticos y crearon una democracia nueva y poderosa. 
Eran, al tiempo, modelos racionales. Ahora la piedad, el valor, etc., serían comportamientos definidos racionalmente, valdrían de una vez para siempre. Su racionalismo, parece, llevaba a algo antiguo, tradicional. Así Tovar. Más tarde yo, que accedía entonces al conocimiento de los antiguos griegos, lo proponía también en un artículo "Tradition et raison dans la pensée de Socrate» ${ }^{6}$.

En él señalaba yo que pensadores atenienses como Solón, los trágicos, Tucídides, se interesaban, antes que por cualquier otra cosa, por los temas morales y políticos. Sócrates era antes que nada un ciudadano ateniense: en esto estaba su diferencia con los sofistas apátridas, que aplicaban al hombre un racionalismo relativista y destructor ${ }^{7}$.

Añadía Sócrates, es claro, un tratamiento intelectual, quería definir las virtudes y asegurarlas para Atenas, para toda la Humanidad incluso, para siempre. Tenía fe en la razón. Interiorizaba las reglas de conducta, añadía el «cuidado del alma». Era un reformador que nunca tuvo un matiz antirreligioso.

Esta era, pensaba yo, la raíz de su pensamiento: el intento de recuperar al ateniense tradicional y virtuoso de la antigua tradición, conocedor ahora de definiciones racionales de las varias virtudes, que pondría al servicio de Atenas y aun de la Humanidad. Claro que quedaban dudas en torno a la religión y a cómo Sócrates concebía a los dioses. Ahora diré.

Claro que esto, que Tovar trasladaba a la joven generación española de entonces, que entre otras cosas aportaba un nuevo conocimiento de la antigua sabiduría, se reveló un tanto ingenuo y carente de éxito, como a Sócrates le había sucedido en Atenas. Al menos, ahí quedaba, como pendón al viento, un nuevo ideal para toda la Humanidad. Y se desmontaba la visión relativista de los sofistas. Se abría la posibilidad de una moral, una conducta, accesible a todos, que partía del cuidado del alma.

\section{Sobre la Religión de Sócrates y los nuevos pasos de su Filosofía}

Antes de seguir adelante voy a insistir en el debatido tema de la religión de Sócrates. Tema difícil en sí, pero importante para la exposición de su pensamiento. $\mathrm{Y}$ tema complicado por las diferencias que varios autores encuentran

${ }^{6}$ Rodríguez Adrados 1956.

7 Cf. Lefka 2005. Platón conservó hasta su muerte su adhesión a estos principios. La muerte de Sócrates es una especie de contrarreforma. 
entre la visión que nos ofrece Platón y la que nos ofrece Jenofonte, más convencionalmente religiosa esta última.

¿O es que el Sócrates de Jenofonte era el verdaderamente religioso, menos el de Platón? Ya antes hice esa pregunta, muchos la han hecho también. ¿Y qué relación había con Platón en lo religioso? ¿Identidad, enfrentamiento, o la que hay entre algo que comienza y algo que va más allá luego? ${ }^{8}$

Son varios los artículos recientes que inciden en el tema de la religión de Sócrates, sobre todo según Jenofonte, en cuanto va más lejos de un puro ritualismo o legalismo. Las dos Apologías y otros datos insisten en que no puede ponerse en duda el cumplimiento por parte de Sócrates del rito y su proximidad a la religión de Delfos, es conocida la famosa consulta de Querefonte y la respuesta del dios: Sócrates era el hombre más sabio ${ }^{9}$. Y se sabe de su daimónion, ya hablé de él, su relación con él la justifica él mismo hablando de su proximidad a la mántica.

Pero, sobre todo, sobre la religión de Sócrates hay hoy que apoyarse en varios trabajos recientes, por ejemplo, los de una obra de múltiples autores, la dirigida por Nicholas D. Smith y Paul B. Woodruff, Reason and Religion in Socratic Philosophy ${ }^{10}$. O un artículo de R. Janko ${ }^{11}$. O varios trabajos dirigidos al estudio comparativo del Sócrates platónico ${ }^{12}$. O el estudio de Tomás

${ }^{8}$ Véase Lefka 2005. Según ella, Platón establecería, en la ciudad fundada en las Leyes, una religión establecida sobre el logos, de origen socrático.

9 Sería un mito, según Montuori 1974. Mera conjetura.

${ }^{10}$ Smith y Woodruff (eds.) 2000. Véanse, entre otros, los artículos de R. Kraut, «Socrates, politics and religion» (el daimónion sería un recurso para desmontar las instituciones religiosas tradicionales); C. D. C. Reeve, «Socrates the Apollonian?» (sería algo utilizado contra Sócrates); R. Parker, «The trial of Socrates, a religious Crisis?» (procedería del relativismo sofístico, el Sócrates de Aristófanes): G. Vlastos, «Socratic Piety» (la moralización y racionalidad de los dioses iba contra la religión tradicional); Th. C. Brickhouse y N. D. Smith, «Socrates, gods and the daimonion» (moralización de los dioses por Sócrates, el daimónion no sería necesariamente algo irracional); M. L. McPherran, «Socrates and Plato on Prayer and Sacrifice» (discrepancia de Atenas y Sócrates sobre el culto); A. Gocer, «A new assessment of Socratic Philosophy of Religion» (no se encuentra en Sócrates la pretendida bondad de los dioses); P. Woodruff, «Socrates and the Irrational» (rechazaría tanto el racionalismo sofístico como la tradición religiosa); St. A. White, «Socrates at Colonus» (sobre el Sócrates heroico del Fedón). Siguen cartas de varios filólogos sobre el daimonion.

11 Janko 2002-2003.

12 Véase, sobre Jenofonte, por ejemplo, Calvo Martínez 2008; sobre Platón, Balansard 2002 y Lefka 2005, quien cree que no, los principios socráticos sobre los dioses serían los mismos de la ciudad de Platón. 
Calvo Martínez sobre la religión del Sócrates de Jenofonte ${ }^{13}$. Doy algunos detalles sobre él.

Insiste en su legalismo religioso, su conservadurismo. No se testimonia en él una crítica de las representaciones tradicionales de los dioses ni de ellos mismos. Es más, hay en Jenofonte, puestas en sus labios, referencias frecuentes a su culto a los dioses. Nada hizo contra la piedad o la religión (cf. Mem. IV 7.6) ni criticó las representaciones populares de la divinidad. Y estaba lejos de la corriente crítica de las luces (cf. Mem. IV 3-12) «No descuido lo divino», dijo (Mem. IV 3. 15).

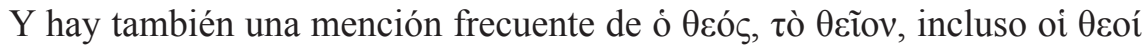
sin notaciones individualistas, algo que podríamos traducir por «la divinidad» o «lo divino». Es un uso griego general, no sólo socrático, recuérdese, por,

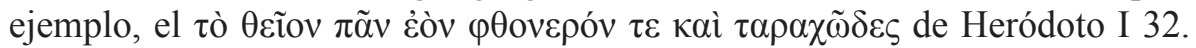
Se ve, este desdoblamiento de lo divino en lo individual y lo genérico o abstracto estaba en el pensamiento griego, Sócrates no hacía en esto otra cosa que seguirlo.

Los griegos, y Sócrates con ellos, iban más lejos que hacer una mera referencia a los dioses tradicionales, individuales, y a su culto. En realidad la oscilación entre el dios individual y el abstracto y genérico puede encontrarse ya, por ejemplo, en Jenófanes ${ }^{14}$, Heráclito ${ }^{15}$ y Esquilo ${ }^{16}$. Sócrates, pues, participaba en la vacilación entre dioses individuales y genéricos, con tendencia al monoteísmo, era una tendencia general entre los pensadores griegos.

Pero en cuanto al racionalismo y el irracionalismo hay mucha discusión en torno al famoso daimónion, si era o no era un ente divino o algo más bien subjetivo ${ }^{17}$.

Las mismas dudas hay en lo relativo a la religión y a cómo Sócrates concebía a los dioses. ¿O es que el Sócrates de Jenofonte era el verdaderamente próximo al de la religión popular, como algunos dicen, menos el de Platón?

\footnotetext{
${ }^{13}$ Calvo Martínez 2008.

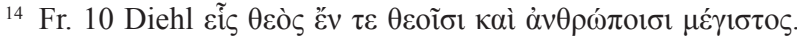

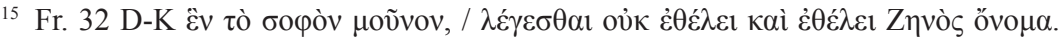

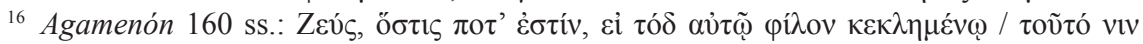
$\pi \rho 0 \sigma \varepsilon v v \varepsilon \dot{\pi} \omega$.

${ }^{17}$ Véase en el libro ya citado editado por Smith y Woodruff, el debate epistolar en páginas 176-204 entre G. Vlastov y varios filólogos: el tema es si debe rechazarse cualquier interpretación contraria al racionalismo de Sócrates o si realmente el daimónion es «una fuente de conocimiento».
} 
¿Y qué relación había con éste en lo religioso? ¿Identidad, enfrentamiento, o la que hay entre algo que comienza y algo que va más allá luego? ${ }^{18}$

En todo caso, en Platón, la idea del Bien, que se ofrece, venida de lejos, a los filósofos reunidos en amistad como una Iluminación, es un ente externo y cuasidivino, desde luego extrahumano y actuante. Es «la parte más brillante del Ser», según República 518 d.

¿Tiene esto algo que ver con el daimónion? También es una culminación del Ser, también proyecta su sabiduría sobre un hombre o sobre los hombres. No parece muy distante, aunque el Bien tiene una superioridad bien clara.

Y esos mismo dioses a los que Sócrates rinde culto, sobre todo en Jenofonte, no es claro que sean otra cosa que receptores del culto. Su origen y su incidencia en la realidad no son precisados. Y ocurre que los estudiosos modernos de Sócrates, Platón y la religión griega en general, son filósofos generalistas más que estudiosos de la antigua religión y el antiguo pensamiento de Grecia. Solón o Esquilo y los trágicos y otros pensadores griegos más creían en la intervención directa de los dioses castigando las conductas viciosas y esta era sin duda una tradición entre las clases conservadoras. Ahora esto no se menciona, en la religión de Sócrates y de otros muchos, ni como posibilidad.

Cierto que este tipo de pensamiento religioso estaba en decadencia en el siglo V, lo conservaban Heródoto y otros, pero no Tucídides, ni Hipócrates ni varios pensadores más. Ni Sócrates.

Sócrates podía conservar los usos habituales de Atenas, no chocar como Anaxágoras cuando decía que el Sol era un pedrusco no más grande que el Peloponeso y tenía que huir de Atenas o como otros sofistas aludidos en Aristófanes bajo el nombre de Sócrates, cuando sustituía a Zeus por el Dinos o Torbellino.

Claro que había otros ilustrados que se declaraban simplemente ateos, así Demócrito, Protágoras o Epicuro. Sócrates intentaba, quizá, simplemente no chocar, además no tenía conclusiones radicales. De un lado hablaba a la manera tradicional del pueblo, de otro simplemente buscaba. Y más sobre la conducta humana que sobre la divinidad.

18 Véanse posiciones encontradas en Lefka 2005. Platón establecería, en la ciudad fundada en las Leyes, una religión apoyada sobre el logos, de origen socrático. Veo esto muy dudoso. Pero, en realidad, en Platón hay a veces la continuación de la religión tradicional, otras su superación en el mundo de las Ideas. 
En cambio, según algunos nuestra imagen de Sócrates viene del siglo IV a. C., es un rechazo, al tiempo, del racionalismo sofístico y la religión tradicional ${ }^{19}$. Me resulta más que dudoso.

Porque hay que plantear una pregunta: ¿qué era un ateo en Atenas? $?^{20}$ ¿El que negaba la existencia de los dioses o el que los degradaba haciéndolos seres lejanos, quizá de átomos más flojos, como Epicuro? Para muchos eran ateos quienes, en la práctica, no contaban con los dioses para explicar lo que ahora se incluía en la Meteorología. Nosotros los llamaríamos más bien agnósticos.

En definitiva, en la Atenas del siglo V había muchos que para multitud de temas (sea la meteorología, sea la vida humana u otros aún), prescindían de los dioses: se adherían a las nuevas ideas o, simplemente, no opinaban. En este tipo de pensamiento estaba Sócrates: desde este punto de vista estos hombres eran ateos ${ }^{21}$. Se abstenían de opinar sobre la intervención divina que proponía la vieja tradición, no entraban en ello, simplemente.

En este sector habría que colocar también a Tucídides, discípulo de Anaxá-

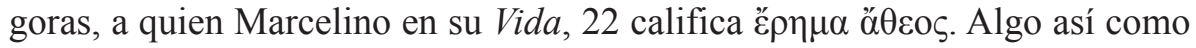
«pacíficamente ateo», una especie de ateo que simplemente prescindía del tema. Eran, sin duda, numerosos en Atenas y en mil sitios más.

Sócrates quería alejar al hombre de la tragedia, alejar de él desastres como los que sobrevenían a los héroes trágicos, buscar soluciones al conflicto y el dolor: había, decía Platón, un antiguo enfrentamiento entre Tragedia y Filosofía $^{22}$. Esta intentaba resolver los enfrentamientos trágicos que crea la vida en sociedad, buscaba soluciones racionales a los conflictos humanos. Soluciones varias que dieron origen a las distintas escuelas filosóficas del Helenismo.

Cierto, Sócrates no creó nuevos dioses sustituyendo a los antiguos, salvo un daimónion más bien tentativo, del que ya hemos hablado ${ }^{23}$ y que era quizá, más bien, una forma de eludir el tema. $\mathrm{O}$, como tantos, se refugiaba en

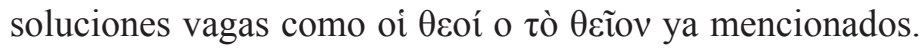

\footnotetext{
19 Así, Woodruff 2000.

${ }^{20}$ Sobre el concepto de ateísmo en Atenas, véase Balansard 2002.

${ }^{21}$ Más radical era Protágoras, que admitía abiertamente que no sabía si existían dioses o no. Cf. Janko, 2002-2003, p. 10.

22 Así Platón, República 607 b. Véase sobre este tema mi trabajo Rodríguez Adrados 1969.

${ }^{23}$ Recuerdo la revisión de opiniones discordantes en un amplio debate en el libro editado por Smith y Woodruff (eds.) 2000, pp. 176-204.
} 
Otros proponen que el enfrentamiento judicial de la ciudad contra Sócrates y su condena a muerte fue el resultado de choques múltiples y de amistades peligrosas, como las de Alcibíades, Critias y otros más. ¿O de choques ocasionales por hechos concretos, como cuando en el 406 Sócrates se opuso a la condena de los generales que no habían podido recoger a los muertos en la batalla naval de las Arginusas, repito el ejemplo? ¿O cuando, poco después, lo dije ya también, se negó a colaborar con los treinta tiranos en acciones criminales?

También se habla de una especie de ola anti-intelectual, una «witch-hunt» comenzada en el 415 a. C., cuando Diágoras de Melos fue condenado a muerte por burlarse de los misterios de Eleusis y Alcibíades fue perseguido por temas semejantes y hubo de huir ${ }^{24}$. Y cosas semejantes se dicen de Anaxágoras y Protágoras. Por otra parte, la acusación contra Sócrates tuvo lugar tras el 403, la fecha del decreto que abolía los delitos por antiguos enfrentamientos. Se ve que se tenía en cuenta o no, según las conveniencias. Leyendo a Lisias se encuentran ejemplos.

Sócrates no cedía, jamás abandonaría la Filosofía por mucho que se lo pidieran, le hace decir Platón en su Apología. Frente a él, pensaba, no había sino una visión equivocada, un error. Representaba una oposición irreductible, una antipolítica que caía mal a los que en el 403 fundaron, tras la derrota del 404, una democracia supuestamente moderada, que quería acallar las voces contestatarias.

Como la de un Sócrates que chocaba con unos y otros, era antipolítico, sin duda no estaba lejos de creer, como Platón poco después en su Carta VII, que toda la política de las ciudades griegas era detestable ${ }^{25}$. Seguirían pasando eternamente de la demagogia a la tiranía hasta que los filósofos alcanzaran el poder, es lo que decía Platón. Bastante erróneamente, ya se sabe de los problemas entre los platónicos en Siracusa.

Pero, sin duda, llegó un momento en que eran demasiados los que pensaban así de los políticos. Aunque los más se limitarían a criticar, a no asistir a la Asamblea (en el mismo 403 el demagogo Agirrio hubo de crear un salario para los que asistieran). Era la hora de la desmoralización política, ahora ya muy generalizada.

Sócrates se convirtió en símbolo de la oposición desengañada y antipolítica. Era la oposición de un hombre que se había quedado solo, incluso habían

\footnotetext{
${ }^{24}$ Cf. Janko 2002-2003.

${ }^{25}$ Cf. Platón, Carta Séptima 324 b ss.
} 
muerto los sofistas Protágoras (415) y Pródico (411), Eurípides se había refugiado en Macedonia en el 407 iy escribió una tragedia de tema religioso llevado al límite, Las Bacantes! (murió el 406 en Pella).

Y en Atenas habían fracasado la democracia, el nacionalismo y la tiranía, se habían quedado, además, sin dioses. Sócrates fue condenado a muerte el 399 por la nueva democracia. Y si Pericles hubiera seguido vivo seguro que se habría arrepentido de su justificación de la democracia de Atenas en su famoso discurso. Protágoras a su vez la había justificado con que todos los hombres tienen lógos. Como Sócrates, creía que eran capaces de convencerse unos a otros. Ahora una ola de pesimismo envolvía a la ciudad.

Fue esa desilusión de la democracia, aumentada por la crisis económica y las derrotas militares, la que trajo un crecimiento de las ideas monárquicas (Jenofonte, ciertas obras de Platón, Isócrates).

Quedaba puesto el decorado para los gobiernos monárquicos regidos por pequeños grupos de militares y burócratas: los de las monarquías helenísticas y Roma. Y para el descrédito de la democracia en los pensadores medievales.

Pero el ideal de la libertad es tan humano, que al cabo de largos siglos resucitó por fin y ahí está, por muchos que sean sus problemas. Sócrates vivió todavía en la democracia y trató de fundamentarla, uniéndola a una nueva racionalidad humana. Esto, entre muchas cosas, hay que decir en su honor.

Y, de otra parte, Sócrates dejaba abiertas muchas cuestiones sobre las que él investigaba y que siguieron investigando sus continuadores. Fue el comienzo de una serie de movimientos filosóficos (y políticos) que llegan a nuestros días.

\section{Sócrates y la Literatura oral: Principios y aVANCES}

No puede comprenderse bien a Sócrates si se deja de introducirlo en el mundo de la oralidad: decimos Literatura oral porque es una expresión consagrada, no es posible encontrar un sustituto, pero contiene algo erróneo, «Literatura» supone las letras, el lenguaje escrito. Sócrates no escribía lo que hablaba con sus discípulos y con cualquiera en las calles o las palestras de Atenas lo conocemos por las concordancias entre los que escribieron lo que le oyeron. En una medida cosas concordantes y pensamos que seguras, pero en otras susceptibles de ofrecer dudas.

Él mismo decía aquello de «sólo sé que no sé nada», buscaba, investigaba. Conocemos, eso sí, algunas de sus frases, sentencias o enseñanzas, del tipo de «sólo sé que no sé nada», «la vida sin examen no es vivible para el hombre», «el 
cuidado del alma». Es uno de los representantes en Grecia de la Literatura oral, que también se encuentra en otros muchos pueblos. Es la que luego es escrita.

De un lado, este es un sector importante de las antiguas Literaturas - la egipcia, la sumeria, las semíticas-, que nos han llegado, en cierta medida, por versiones escritas posteriores. Pero incluso en culturas que ya conocían, con más o menos difusión, la escritura, brotaban y brotan, en edades y lugares diversos, Literaturas orales. En la Edad Media, ahora mismo, en todo tipo de culturas ágrafas que con el tiempo han adquirido, las más de ellas, la escritura. Y en las culturas con escritura, ahora mismo, siguen viviendo junto a ella literaturas orales.

En Grecia, lo oral está en el comienzo de todo: de la épica, la lírica, el teatro, la filosofía. Ya Homero y la épica eran en un comienzo orales, también lo eran en nuestra Edad Media, luego se escribieron en fechas diversas, pero guardaron restos de la oralidad. E igualmente eran orales en principio filósofos como Heráclito, fundadores de Religiones como Jesús de Nazareth (en el texto griego de los Evangelios, sin duda a veces en arameo). Y añadamos Buda, filósofos como Diógenes el cínico y tantos epicúreos y estoicos. Y muchos más, imposible hacer una reseña completa.

Sobre este tema he escrito ampliamente en mi El Río de la Literatura. De Sumeria y Homero a Shakespeare y Cervantes (Barcelona, Ariel, 2013). El hecho es que la Literatura ágrafa la conocemos, en principio, por sólo el oído, otras, cuando se hizo escrita, por la vista. Y con frecuencia las Literaturas escritas conservan muchos rasgos de su origen ágrafo. Las palabras de Sócrates resuenan todavía en nuestros oídos, llegan a nuestra vista, a partir de versiones escritas posteriores, más o menos fieles.

Habitualmente, la Literatura oral era (y sigue siendo) anónima, otras veces se da al autor un nombre tradicional o inventado (Homero, Esopo, Valmiki), pero otras lleva el nombre de un sabio como Ahikar en Asiria o Ptah-Hotep en Egipto o Surrupak en Sumeria o Sócrates en Grecia, también creadores de religiones como Jesús, ya dije: Buda o Mani o Akenatón, primero orales, luego escritores. O puede ser un poeta como Homero o Solón o un profeta como los hebreos.

Sus formas de actuación son varias: cantan o recitan himnos o épica o pronuncian sentencias o proverbios mezclados quizá con fábulas (tal el mismo Sócrates) o símiles, enseñando a un individuo (al propio hijo, al amigo) o a un pueblo, o dialogando, así en las colecciones sumerias o en debates en la Antigüedad y la Edad Media. 
Porque, si bien es cierto que la Literatura oral tiende a pasar a ser escrita, luego revive en fiestas o en la danza o el preteatro, así, por ejemplo, en nuestra Edad Media. Y hay los cantos de trabajo, de la cosecha, del vino y el banquete, del sacrificio e himnos anónimos o no y otras formas de lírica, tal la erótica (religiosa o no), que hallamos con rasgos muy similares en Egipto, en Babilonia, en Grecia, entre los mozárabes españoles, en Galicia, en Provenza. Y los cantos de duelo y los funerarios, los trenos. Entre variantes mil.

Es todo un universo que he estudiado con alguna detención en mi Río. Es multiforme, se transforma, vive en la Fiesta, el trabajo, el funeral. A veces hay transiciones y se hace puramente personal. Y luego es imitada haciéndose personal, por ejemplo en Safo o en García Lorca.

Si traigo aquí a colación todo esto es porque sólo en este ambiente puede comprenderse a Sócrates, en este caso un sabio autónomo, de vida libre, maestro y dialogante en toda Atenas, en los límites entre lo que es, a veces, un maestro religioso y uno profano. Se niega a recibir el nombre de sabio, sólo es filósofo, esto es, amante de la sabiduría, buscador de la sabiduría. Tiene discípulos que son amigos, pero habla con todos, busca instruirlos, cambia sus vidas.

Como los sabios creadores de religiones, a los que he aludido, Sócrates, como otros sabios, iba a la contra: solos o con sus discípulos, chocando a veces con los que se niegan a entender, a aceptar la reforma. A veces sufren muerte, a consecuencia de ello: así Sócrates, así Esopo, así Mani, así, por supuesto, Jesús de Nazaret.

\section{Sócrates: LeNGUA, ESTILO, FILOSOFÍA}

Son venerados a su muerte, así varios de los citados o Mahoma o Buda. Igual los personajes del Carnaval -estos sabios aparecen con frecuencia en la Fiesta, el Carnaval es sólo una de ellas-, así el propio Carnaval y la Vieja, su equivalente en otras versiones.

Sócrates tiene el estilo propio de esos maestros populares, errantes, controvertidos. No tienen el estilo regularizado de la prosa, sino el libre de la lengua popular, de la sátira y el duelo otras veces. Sobre esto he escrito en relación con Sócrates: un artículo sobre la lengua de Sócrates y su filosofía ${ }^{26}$. Y la forma tiene mucho que ver con el contenido. Este es un tema notable, apenas estudiado.

\footnotetext{
${ }^{26}$ Rodríguez Adrados 1992.
} 
Sócrates, en la medida en que, a partir de versiones posteriores, podemos acceder a su obra y al lenguaje de la misma, no se acomodaba a ningún género literario o, si se quiere, creó un género literario nuevo, seguido luego por discípulos e imitadores: el Diálogo socrático. Es notable que en escritores tan diferentes como Aristófanes, Jenofonte y Platón encontremos testimonios de la lengua y estilo de Sócrates absolutamente concordantes, mientras que sólo en parte podemos decir esto de los testimonios de su doctrina.

Hablaba - y eso se refleja en su transmisión escrita en un griego popularhabitualmente en diálogo, estaba alejado del «discurso largo» de sus rivales los sofistas. Se acompañaba de abundantes símiles y comparaciones, de abundantes mitos y fábulas, de comparaciones de nivel popular o familiar, de anécdotas, de parodias, de la ironía, de paradojas, de interrogaciones, de la

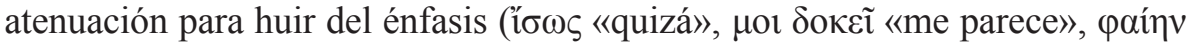
őv «yo diría»). Abundan también en él los recursos impresivos y expresivos.

La sintaxis es a veces laxa, llena de incisos secundarios, de anacolutos. El léxico no es vulgar, como puede ser el de los cínicos, pero sí popular y a veces creativo, para insistir. Elige términos que a veces son nuevos, en todo

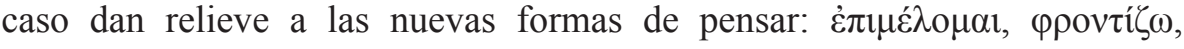

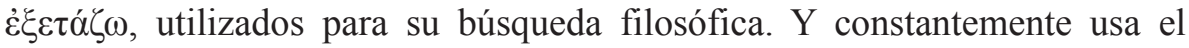
diálogo, la exclamación, la interrogación como dije. Es invento suyo la ironía, que le debe su nombre, sịpóvela.

Todo esto está conectado con la marcha que quiere dar al diálogo, que ya es lento, ya rápido, ya cómico, ya agresivo. Sócrates es dueño de su lengua, es creativa, puede compararse a veces con la del teatro o la sátira.

Esto tiene que ver con sus temas, tan variables, en los que se incluyen dichos de sabiduría (suyos o tradicionales). Estos eran diferentes por lo demás de los de otros géneros orales: relatos épicos, manifestaciones religiosas o poéticas. Hay cambios según las fechas y las variantes temáticas: en Grecia está próximo, pero también distante, Diógenes el cínico, notable por sus anécdotas chispeantes, por sus burlas.

Lo notable de Sócrates, semejante a tantos sabios y consejeros populares, es que negaba ser un sabio, tampoco era un reformador religioso. En realidad, inauguraba una nueva sabiduría. No solo suya, tuvo infinitos herederos, continuadores, adversarios. Puede decirse que de él salieron todas las filosofías, de los estoicos a los epicúreos y a tantos más.

Claro que luego vino la sabiduría que llamaríamos «de libro», en parte en el mismo Platón el diálogo es intermedio entre una herencia de Sócrates y un 
diálogo que en realidad encubre una obra doctrinal, un tratado sobre varias ciencias y técnicas. Aristóteles, las obras de él que conservamos, no sus primeros diálogos, está ya muy lejos.

En realidad Sócrates es algo único en el mundo, cultiva una especialidad muy suya dentro del mundo de lo oral. Pueden compararse en parte diversas obras doctrinales como por ejemplo las Upanishad en la India, diálogos sobre temas religiosos y varios, y, en diversas culturas, obras que oscilan entre lo doctrinal y la pura creación en diálogo, con elementos creativos y pintorescos varios: fabulísticos, novelescos, anecdóticos. Se encuentran en la Antigüedad tardía y en nuestra Edad Media. Pero, claro, no son Sócrates.

\section{SÓCRATES: SU DRAMA Y SU MUERTE}

Ya hemos ido viendo el drama de Sócrates: con todo su atractivo personal, su falta de énfasis y dogmatismo, su apariencia de rudo Sileno pero con estatuas de dioses dentro ${ }^{27}$, estaba rodeado de conflicto. Su eterna búsqueda, su inconformismo con la moral y los hábitos sociales tradicionales, su no ceder ante la injusticia, le colocaba siempre al riesgo del roce y aun del choque. Y más en los últimos tiempos, con Atenas a punto de sucumbir ante un enemigo al que despreciaba y, por otra parte, llena de tradicionalistas fanáticos que echaban a los «modernos» la culpa de sus desgracias.

Buscaban un chivo expiatorio para mostrar su poderío. Y Sócrates, un tipo popular que era al menos dudoso en cuanto a su religión y su modo de ser, sin defensa, de otra parte, por un nacimiento o una riqueza importantes, un hombre sin partido que intimaba con todos y con todos era amigo de relacionarse, pero no cedía ante nadie en sus ideas y sus lealtades, ni era comprable de una manera $u$ otra, era una buena elección. Era un verso suelto demasiado libre, demasiado débil. Este era su drama.

Era un reformador, ya dije y eso choca siempre con la rutina de todos los días. Y más el que, aunque decía que no era un sabio, sí lo era. Y era optimista, no veía el peligro.

Con esto me refiero no sólo a su persona, sino a su tipo humano. Hemos visto, páginas atrás, la suerte de varios de ellos, he hablado de la suerte, cierto que en la leyenda, de un sabio popular como Esopo, traidoramente asesinado, podría añadir el Ahikar asirio, la obra en que el rey Sennaquerib

${ }^{27}$ Palabras de Alcibíades en Platón, Symp. 215 a-b. 
recibe la ayuda del sabio Ahikar y éste adoctrina con máximas y fábulas al malvado hijo del rey, Nadan, y acaba muerto por él. En Atenas no había rey, pero Sócrates aleccionaba al pueblo y fue muerto por los jueces populares.

También hay que recordar cómo Mani, en el Irán, primero favorecido por el rey, luego perseguido y muerto ${ }^{28}$, creó la religión maniquea que se extendió hasta China y España. Pero fue visto como rival, fue perseguido y muerto, esto en el siglo III d. C. La historia de Cristo es conocida, nunca había tocado un arma pero fue perseguido como «rey de los judíos», crucificado. Otras veces no hay hechos de sangre, Buda murió en su lecho, recibió culto luego, pero sus discípulos fueron perseguidos, el Budismo fue arrancado de la India, sólo pervivió en Ceilán y gran parte de Asia. Akenatón, el gran reformador religioso de Egipto, pudo vivir su reforma en su nueva ciudad de Tell-elAmarna, pero a su muerte su religión fue perseguida con saña.

Este es el destino de los que buscan el poder con un programa que a muchos atrae, pero no a los que defienden el suyo, así acabó Julio César. Pero ahora me refiero a un programa intelectual, una nueva religión o una nueva sabiduría.

Pero volvamos a Sócrates ${ }^{29}$.

Sócrates era tenaz y sin miedo. Cuando 280 miembros del tribunal de la Heliea, le pidieron que señalara la pena, era legal, dijo con insolencia que proponía ser alimentado de por vida por el Estado en el edificio del gobierno, el Pritaneo - del cual eran huéspedes grandes benefactores de la ciudad-. El tribunal, irritado, le condenó a muerte.

Hay que leer, en el Fedón platónico, la muerte del maestro, cómo, rodeado por sus discípulos, bebió la cicuta con serenidad. Esta es la idea que nos ha quedado de Sócrates, el héroe del pensamiento. Su modelo está, efectivamente, en la muerte del héroe en Homero, un Aquiles que prefiere la muerte a una indignidad sin gloria ${ }^{30}$. O de la heroína Antígona en la tragedia de Sófocles que lleva su nombre ${ }^{31}$. Prefiere morir antes que obedecer al rey Creonte y desatender una obligación moral y religiosa, la de enterrar a su hermano.

\footnotetext{
${ }^{28}$ Véase Magris, 2000, p. 107 ss.

29 Véase Rodríguez Adrados 1998.

${ }^{30}$ Cf. Ilíada IX 412 ss.

${ }^{31}$ Sófocles, Antígona 447 ss.
} 
Este es el pasaje:

Creonte. ¿Sabías que se había prohibido hacerlo?

Antígona. Lo sabía, ¿cómo no? Era público.

Creonte. ¿Y osaste violar esa ley?

Antígona. Sí, porque no fue Zeus quien la promulgó, ni la Justicia, que mora con los dioses infernales, señaló una ley tal entre los hombres, ni creía que fuesen tan poderosos tus decretos que pudieras, siendo hombre mortal, pasar por encima de leyes no escritas e inmutables de los dioses. No son de ahora ni de ayer, sino que están vivas siempre y nadie sabe de dónde han venido ... Y si muero antes de tiempo, lo considero una ganancia, pues al que como yo vive en medio de desgracias, ¿cómo no va a llevarle beneficio la muerte?

Es decir, frente al poder arbitrario del rey o de un tribunal hay héroes que prefieren seguir las leyes inmutables tradicionales. Sócrates, en Platón, dice lo mismo: obedeceré al dios antes que a vosotros.

Y era el hombre que buscaba. Pero al menos en este punto la tradición le era suficiente. Coincidía, de otra parte, con las reglas de humanidad, de conciencia, que él seguía.

\section{SÓCRATES: POLÍTICA Y MORAL}

Pero el tema es el de la política y la moral. Porque en el piélago de la incertidumbre, la desesperación de la Atenas de fines del siglo V, Sócrates no encontró una fórmula que uniera esos dos polos. Se refugió en el derecho de cada hombre a poner por delante la moralidad, a no adherirse a los poderosos, sean éstos un hombre o el del resultado de una votación. Prefirió morir, ser la víctima. Hermoso para el individuo, pero inaplicable como fórmula política.

Es la fórmula que consiste en rechazar la política, sustituirla por la pura moralidad, hasta consecuencias extremas. Según ellas, tras aceptar la democracia, el hombre se reserva para su persona un derecho individual para quedar aparte por razones morales, sean cuales sean las consecuencias. Platón fue más lejos: moral y política eran lo mismo o, mejor dicho, no aceptaba la política fuera de la moralidad, la abolía prácticamente. Aristóteles fue más práctico en su Política, estableció una República de clases medias, moderada, basada más

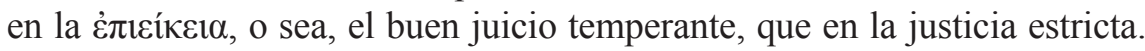

Cuando en ciertos momentos de Roma o, sobre todo, en la época del $\mathrm{Hu}-$ manismo y luego en las democracias modernas, llegó de nuevo el tema del 
individuo y el estado, ahí quedaba el problema. Hubo que tratar de buscarle soluciones, al menos parciales, y hubo otras veces que soportarlo. Sócrates fue, sin duda, uno de los hombres que más hondamente lo vieron y lo vivieron. Nos ha dado, al menos, claridad, pero una luz definitiva tampoco nos ha dado.

No se puede juzgar a Sócrates sin conocer cuál fue su vida, cuál fue la de la ciudad. Sobre esta tenemos datos, sobre la vida de Sócrates muchos menos.

Sí, ya sabemos de su amor a la ciudad, de su adhesión a las instituciones de atenienses, resignándose a soportar lo peor. Pero no podemos conocer en detalle los momentos sucesivos por los que pasó. Con valor, sí. Ya sabemos que fue hoplita en Potidea en el 432, también en Amfípolis y Delion, a partir del 432, cuando tenía ya 37 años y más. Y conocemos los episodios que vivió en fechas posteriores, ya en el 406 y después, con Sócrates ya viejo.

Cumplía su deber, lo primero, reaccionaba contra la injusticia, después, eso es todo. Pero, ¿cómo llegó a esto? ¿Cuáles fueron sus experiencias en la vida política de Atenas? Lo más que podemos hacer es imaginar algo de ello.

Nacido en el 469, no vivió ya la época gloriosa de la lucha por la libertad contra los persas y la fundación de la Liga Marítima el 477. Y tampoco pudo conocer, en su infancia, el enfrentamiento de la democracia conservadora de Cimón y la más radical de Efialtes, asesinado el 461, y su continuación bajo Pericles: la guerra en dos frentes, la paz con Persia en el 449 y con Esparta el 446. En este momento tenía 23 años, ignoramos si participó en alguna de estas guerras.

Luego hubo de vivir los años de la paz de Pericles, del Partenón, de la llegada a Atenas de los representantes de la nueva intelectualidad: de sofistas como Protágoras, del físico Anaxágoras, del escultor Fidias, del astrónomo Metón, del urbanista Hipódamo, del músico Damón, de Aspasia la milesia, su compañera, un nuevo prototipo de mujer ${ }^{32}$.

Eran años que llenaban a Pericles del optimismo de su discurso en honor de los muertos en el primer año de la guerra del Peloponeso, iniciada por él en el 431: fue una decisión equivocada. Atenas era la ciudad abierta a todos, la que unía el brillo literario y artístico con la libertad y la ayuda al pueblo.

Representaba una apertura a todo lo humano, pero no todo era tan brillante en ella, hay un tanto de propaganda en el discurso de Pericles que conocemos por Tucídides ${ }^{33}$. ¿Estaría unido Sócrates a las ideas de los físicos y los sofistas (como luego diría Aristófanes el 423)? ¿O estaría en el grupo más conservador

\footnotetext{
32 Véase Rodríguez Adrados 2003.

33 Véase mi análisis en Rodríguez Adrados 1966, p. 266 ss.
} 
de Sófocles y de Tucídides el de Melesias? ¿Comenzaría ya su oposición al relativismo sofístico, tan fuerte luego? No lo sabemos, podemos sólo suponerlo.

Ni conocemos hasta fecha mucho más tardía su participación en la guerra del Peloponeso, aunque existió, ya he dicho, al menos en sus primeros años. Y esa guerra estuvo llena de desgracias: victorias primero, luego muchas derrotas, luchas civiles cruentas entre los partidarios de Atenas y los de Esparta, miseria y enfermedad en la ciudad prisionera en sus murallas, actos de brutalidad en Melos y en tantos lugares, abusos de los demagogos, imposibilidad de la paz, saboteada siempre. Y todo se agravó desde la derrota en Sicilia en el 415, y luego más con guerras civiles internas, en la flota y en la misma Atenas: golpes reaccionarios como el del 411, «democráticos» el del 409 otros más.

¡Tanta distancia entre la humanidad y la belleza, de un lado, y la miseria humana del otro! ¡Tanto partidismo irracional!

Pues esto es lo que encontramos en los últimos años de guerra de una ciudad como Atenas, modelo de libertad y belleza para todos los griegos. Sócrates, acusado el 399, se liberó a sí mismo de tanta desgracia en forma individual, casi un suicidio. Platón, su discípulo, quiso una solución para todos, la sustitución de la política por una moralidad reglamentista y clasificatoria de los seres humanos.

Pasó la guerra y llegaron las monarquías helenísticas más o menos filantrópicas, y en Roma una democracia tentativa que tampoco duró y un imperio más o menos humano, según los emperadores, y nuevas guerras, nuevas alternativas.

Ya desde el 406, hemos visto el valor desesperado de Sócrates en situaciones miserables. Es bien lógico que le tentara el desprecio por toda política y que al final quedara arrinconado por todos. Por mucho que lo admiremos, su valor suicida no puede separarse de esto.

La búsqueda de comportamientos humanos y morales en política quedó ahí como una bandera para todos, como algo a buscar. Después de Platón, el problema quedó para todas las edades, ha dado vueltas y vueltas, entre tentativas, éxitos aunque sean parciales, fracasos. Cada cual pensará a su manera. Nadie lo planteó con tanta claridad como los griegos y, sobre todo, Sócrates.

\section{BIBLIOGRAFÍA}

Balansard, A. 2002: «À propos de l'accusation de Socrate pour athéisme: la cité des Lois résout-elle le conflit entre le philosophe et la cité?», en Dorival, G. y Pralon, 
D. (eds.), Nier les dieux, nier Dieu. Actes du colloque organisé par le Centre Paul-Albert Février (UMR 6125) à la Maison Méditerranéenne des Sciences de l'Homme les ler et 2 avril 1999, Aix-en-Provence, pp. 51-67.

Calvo Martínez, T. 2008: «La religiosité de Socrate chez Xénophon», en Narcy, M. y

Tordesillas, A. (eds.), Xénophon et Socrate, Actes du colloque d'Aix-en-Provence (6-9 novembre 2003), Paris, pp. 49-64.

Dupréel, E. 1922: La légende socratique et les sources de Platon, Bruselas.

Fréret, N. 1738: De Socrate iuste damnato, Leipzig.

Gigon, O. 1947: Sokrates, sein Bild in Dichtung und Geschichte, Berna.

Gómez Robledo, A. 1966: Sócrates y el socratismo, México (2 $2^{\mathrm{a}}$ ed. corregida y aumentada, México 1988).

Janko, R. 2002-2003: «God, Science and Socrates», BICS 46, pp. 1-18.

Lefka, A. 2005, «Religion publique et croyences personnelles. Platon contre Socrate?», Kernos 18, pp. 85-95.

Magris, A. 2000: Il Manicheismo. Antologia dei testi, Roma.

Montuori, M. 1974: Socrate, fisiologia di un mito, Florencia.

Rodríguez Adrados, F. 1956: «Tradition et raison dans la pensée de Socrate», $B A G B$ 4, pp. 27-40 (recogido en Palabras e ideas, Madrid, 1992, pp. 233-249).

Rodríguez Adrados, F. 1966: Ilustración y Política en la Grecia clásica, Madrid.

Rodríguez Adrados, F. 1969: «El Banquete platónico y la teoría del teatro», Emerita 37, pp. 1-28 (recogido en Palabras e ideas, Madrid, 1992, pp. 353-389).

Rodríguez Adrados, F. 1992: «La lengua de Sócrates y su filosofía», Méthexis 5, pp. 29-52 (recogido en Palabras e ideas, Madrid 1992, pp. 251-278).

Rodríguez Adrados, F. 1998: «La muerte de Sócrates», en López de Juan, C. y Plácido, D. (eds.), Momentos estelares del mundo antiguo, Madrid, pp. 81-93.

Rodríguez Adrados, F. 2003: «Aspasia: algunas propuestas», en Cavallero, P., Buzón, R.P., Frenkel, D. y Nocito, A. (eds.), Koronís. Homenaje a Carlos Ronchi March, Buenos Aires 2003, pp. 79-86.

Smith, N. D. y Woodruff, P. B. (eds.) 2000: Reason and Religion in Socratic Philosophy, Oxford.

Tovar, A. 1947: Vida de Sócrates, Madrid (2a ed. 1954).

Woodruff, P. B. 2000: «Socrates and the irrational», en Smith, N. D. y Woodruff, P. B. (eds.) 2000: Reason and Religion in Socratic Philosophy, Oxford, pp. 130150 .

\footnotetext{
Fecha de recepción de la primera versión del artículo: 07/04/2013

Fecha de aceptación: 05/06/2013

Fecha de recepción de la versión definitiva: 17/07/2013
} 